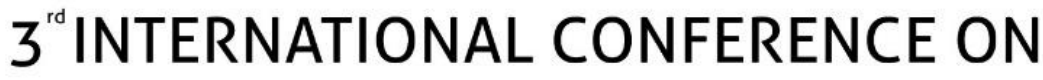 FUTURE OF TEACHING \& EDUCATION
}

Stockholm, Sweden

9-11 October 2020

\section{Challenges of School Career Counsellors Working With Pupils Remotely}

\author{
Rita Burceva \\ Rezekne Academy of Technologies
}

\begin{abstract}
.
In Latvia the organisation of study process at schools changed rapidly during the 1st half of 2020 - classroom activities could no longer be carried out because in the effort to control the spread of the COVID-19 infection, the state of emergency was declared and all schools were closed. The aim of this article is to establish and analyse the key challenges that school career counsellors experience in their professional activity under these conditions. The research questions this article seeks to answer are what professional challenges are characteristic of the school career counsellor's work with pupils of general and vocational education institutions remotely and what are the possible ways of tackling them. The data was obtained through the use of a focus group discussion method that is a format for the design of qualitative research. There were two main questions raised in the focus group discussions: the key problems of purposefully organising communication with pupils remotely within the scope of career education, and the potential solutions and the good practice examples worth sharing with colleagues, ensuring the transfer of knowledge and thus enriching the learning environment for pupils. School career counsellors are recommended to use and improve their pupils' and their own management skills creatively, to be determined to trial new tools for remote work in groups and individualised counselling sessions, to do it not only under the conditions of crisis but also to combine these tools successfully with meeting various audiences in person (pupils, their parents colleagues, cooperation partners from outside of education institutions).
\end{abstract}

Keywords: career education, digital tools, good practice, individual counselling, solutions

\section{Introduction}

The dynamic situations in the life of society and on the labour market create the necessity for every individual to study continuously and to adapt themselves to all ongoing changes throughout their life. This necessity facilitates to the creation of new professions, the development of technologies, the abundance of diverse information and the specific requirements of the new generation towards employers. All these factors make it more complicated for young people to take career decisions. It equally causes anxiety to pupils faced with tough choices that would have an impact on their future career prospects, as it does to their parents who want to support their offsprings during this serious stage of their life.

\section{info@icfte.com_www.icfte.com}




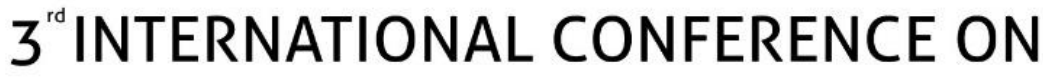 FUTURE OF TEACHING \& EDUCATION}

A large number of general education and vocational education institutions employ school career counsellors who are adequately qualified to get involved in the provision of career development support to pupils. A school career counsellor is a mediator and a facilitator of cooperation among all parties involved - pupils, their parents, subject teachers, the administration of a school and the support personnel, providing methodological, informative and consultative individualised support to pupils during their decision making process of informed and logic career choices. The support that the school career counsellors provide to pupils and their professional duties are diverse: it is the search for a suitable education institution or a suitable profession, the exploration of a young person's talents and the determination of the person's strengths, competitive advantages, the encouragement to embark upon something new, the provision of a competent support service in the development of a $\mathrm{CV}$, a cover letter, the assistance in preparing for a job interview, the alignment with the labour market and life-long education. A school career counsellor prepares and provides the necessary information to pupils and their parents, advices and educates regarding the development of a career during a specific phase of their life, carries out methodological and research activities, and improves his/ her own professional qualification on an ongoing basis as it is set out in the professional standards. All this does not impose restrictions on the school career counsellor's capability to perform his/ her professional duties in collaboration with other teachers, the management and the support team (social educator, psychologist, special educational needs teacher) of an educational institution, the young person's parents and other parties involved.

In Latvia there have been a few separate studies conducted and there are some articles written in the compilations of materials for international scientific conferences on the development of career management skills of pupil and adult job seekers, on the support system for career development in general and the lack of it during the specific phases of education, but the professional activity of school career counsellors, the development of their professional identity and other specific aspects have never been studied. Moreover, in Latvia, similarly to Europe and in the rest of the world, the organisation of study process at schools changed rapidly during the $1^{\text {st }}$ half of 2020 - classroom activities could no longer be carried out because in the effort to control the spread of the COVID-19 infection, the state of emergency was declared and all schools were closed. On the one hand, under these uncomfortable circumstances school career counsellors had to abandon the routine working conditions and format, on the other hand, they had to continue looking for other ways to perform their professional duties, taking care for the interests of their clients - pupils.

The aim of this article is to establish and analyse the key challenges that school career counsellors experience in their professional activity under these conditions, when face to face meetings with pupils are impossible. The research questions this article seeks to answer are what professional challenges are characteristic of the school career counsellor's work with pupils of general and vocational education institutions remotely and what are the possible ways of tackling them.

The conclusions obtained can be used in the future for the improvement of professional qualification of school career counsellors through methodology courses, the good practice can be disseminated in seminars and meetings of the members of the Latvian Association for Career Development Support. Such a perspective determines the practical significance of the research. 


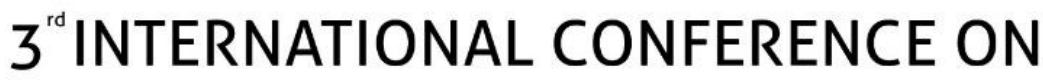 FUTURE OF TEACHING \& EDUCATION}

Stockholm, Sweden

9-11 October 2020

\section{Methods}

The data was obtained through the use of a focus group discussion method that is a format for the design of qualitative research. There were two focus group discussions arranged on the Zoom platform because all participants had access to this tool and they were familiar with it. Both discussions took place in May 2020 when the study year was coming to an end in Latvia and the school career counsellors were ready to evaluate the course and results of their professional activity. Structurally each discussion consisted of 3 stages: preparation, process and feedback or the evaluation of results. There were 12 school career counsellors involved in the focus group discussions representing city and country schools, and representatives of management teams of 4 schools (heads and deputy heads). The discussion participants were selected according to the following criteria: the topic knowledge and work experience in the questions of the discussion. The duration of each focus group discussion was approximately 1 hour. There were audio recordings prepared for both discussions and the interpretation of their content and the content analysis were conducted in order to identify the significant content units for the research, to describe them and to reveal their true meaning.

There were two main questions raised in the focus group discussions: the key problems of purposefully organising communication with pupils remotely within the scope of career education, and the potential solutions and the good practice examples worth sharing with colleagues, ensuring the transfer of knowledge and thus enriching the learning environment for pupils in other general education and vocational education institutions.

The research data collection was limited by the fact that it was possible that the discussion did not cover the whole range of problems the school career counsellors face when organising their work remotely, and some very specific questions only observed at some education institutions may not have been analysed. However, it produced findings on the significant aspects that have an impact on the content, form and quality of career development support, which can be used in further researches in the future.

\section{Results}

During the course of both discussions the participants reflected on their personal experience and pointed to various professional challenges that had come into existence, organising the remote career development support for pupils and students of general and vocational education institutions.

- The ability of a school career counsellor to develop a dialogue remotely because, given the new circumstances, pupils are under the constant influence of values and lifestyles of their family, relatives, friends and the surrounding environment that can have a negative effect on the pupil's career decision making process. It is undeniable that family traditions and the parents' position play an important role in the child's career decision making process because the decision made may depend on the distance between the place of residence and the selected education institution, the family's social status and financial abilities, the child's self-esteem and ambitions for instance. The school career counsellor's ability to "read" and understand the 


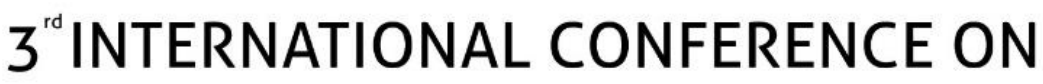 FUTURE OF TEACHING \& EDUCATION}

actual needs and objectives of his client emphatically in order to provide maximum support becomes very important.

- The flexibility and readiness to work under the conditions of uncertainty, the desire to master additional computer skills enabling school career counsellors to develop new methodological materials for career support in a digital form, the ability and skill to select, analyse and evaluate the required information critically, to make use of his and his pupil's limited time resources thoughtfully.

- Erudition and the depth of knowledge in the labour market and the trends of development of various economic sectors under the new circumstances, the offering of vocational and higher education institutions, at the same time also being able to give an adequate explanation to the pupil's needs through individualised consultations.

- The skill of using digital tools in the virtual space, the ability to offer the most suitable professional skill, personality tests that determine the person's strengths and to interpret the obtained results in order to create an individual career development plan, which is specific and achievable in the nearest future, based on the young person's expectations, competences and the system of values. The internal training is organised for teachers of education institutions, librarians, special needs teachers and school career counsellors for the purpose of introducing them to new, previously unused tools of remote work with pupils: MS Teams, Cisco Webex, Zoom, Whereby, Slack, Skype, Google Hangouts, Google Classroom etc. These possibilities allow them to record events, speeches, lectures, instructions, discussions and conferences, thus increasing the number of educational content users. The school career counsellors have also busted the myth of pupils as digital citizens because as often as not they lack the necessary skills to work with digital tools for the purpose of learning and studies.

- Maintaining confidentiality is as a mandatory component of any individualised consultation, along with tackling ethical dilemmas, respecting the requirements of personal data protection and working under remote working conditions. Pupils require the words of encouragement regardless of the form of education process, whether it is done in person or remotely. However, according to the school career counsellors, sometimes the young people are concerned about the possibility of making a recording of the given career advice without their knowledge, or they are concerned that the received support might not meet their expectations when they have not had an opportunity to meet with the school career counsellor in person, or that the conversation with the school career counsellor might be overheard by their parents staying behind the closed door, etc.

- Methodological and research work includes the ability to process, visualise, analyse and present the obtained data, developing supporting materials for pupils, their parents, colleagues, the management of an education institution and the media. The remote work is better integrated in schools and colleges where the proven channels of communication, such as an e-class group, Mykoob or WhatsApp, are in place and are used skilfully for years. In this way the presentations used in remote classes and seminars, electronic links and digital resources, instructions, the created visual, video and audio materials about the education institution, as well as the analysis of the CV and cover letters, etc. developed together with a pupil can be sent to target users directly. Some school career counsellors have ascertained that a consultation can be made more efficient through the use of several tools at the same time, such as, showing a content unit (a 


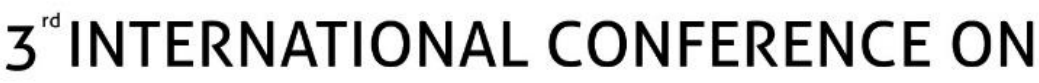 FUTURE OF TEACHING \& EDUCATION}

\section{Stockholm, Sweden}

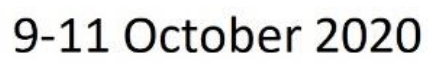

visual aid or several visual aids at the same time, a test, an electronic link, etc.) online and explaining and interpreting the displayed information, results, infographics, etc. The school career counsellors are experts of their field, nevertheless they conclude that under the remote working conditions it may be difficult to use the whole variety of consulting work methods and to receive timely feedback on the carried out activity.

- Some participants of the discussion revealed that the poor knowledge of foreign languages is still a disturbing factor in the methodological and research work, preventing them to learn and adapt the methods and resources used in career advice in other countries.

- Working from home has had an impact on the balance between work and private life. On one hand, technologies provide an opportunity to get in touch with a client at any time and from any location, and it is mutually acceptable in terms of the results and efficiency of such a consultation. On the other hand, both parties involved must have access to adequate technical equipment, including optimum computer hardware, a mobile phone with proper functions, and an uninterrupted internet connection as the essential elements of making it work. The school career counsellors are also concerned about the changing quality of the provided Internet connection, the increased workload in responding to all questions received from pupils by email, giving feedback on the test and questionnaire results, and getting in touch with the pupils' families. The vague limits of the working conditions create preconditions for the signs of job burnout.

- The school career counsellors' initiative, desire to share their knowledge with their colleagues, to self-educate and the motivation to improve professionally. The existence of publicly accessible collections of career development support materials, where every subject teacher can select something for a particular learning situation, a teaching aim that is suitable for the pupils' age range will play an important role. The school career counsellors planned their time successfully and used an opportunity of participating in educational online seminars, discussions, webinars on various topics of career support, interesting methods in working with pupils, team building, and the use of digital tools for counselling. The school career counsellors tested the new methodological materials mutually in order to evaluate their suitability for the specific target groups.

- Constructive cooperation with the management of an education institution, entrepreneurs, representatives of local councils and government institutions. A lot of time resources are spent working with Classes $8-12$ pupils, who must take responsible decisions, but Classes $1-7$ cannot be neglected either, these pupils are equally expected to broaden their horizons on the variety of sectors and professions available to them, and it is necessary to lay the foundation for the development of their entrepreneurial skills and for the exploration of their talents, and to rouse their interest in volunteering. The school career counsellors still face a lack of understanding from their colleagues about the purpose and significance of the work of career support, although it enriches the content of the competence based approach and contributes to the development of transversal skills of pupils. These barriers are usually easy to overcome when the work is done in person. At education institutions, where the management is adequate and subject teachers are open to cooperation for the common goal, a school career counsellor can help a colleague to integrate career management skills meaningfully into the content of various school subjects. The examples of good practice include career counselling combined with a mark in a particular school subject, for instance, the development of a CV and a Cover

\section{info@icfte.com_www.icfte.com}




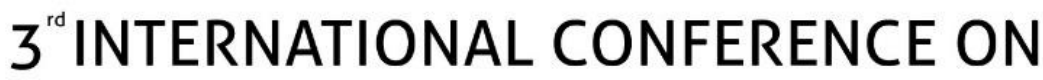 FUTURE OF TEACHING \& EDUCATION}

letter in a foreign language, competitions and quizzes with questions on the career development support in social science, thematic lessons conducted on topics, etc. suitable for different age groups by a class teacher.

- The school career counsellor's understanding of professional values and having respect for their profession. These personal qualities are attributed to the ability to stay calm and treat the difficult clients, the worried children's parents tolerantly, to maintain the pedagogical optimism, and the ability to implement high standards in the routine of their professional activity. During the time period, when it was only possible to offer remote counselling, it was a very productive time for setting the priorities of life right, for self-examination and testing the motto of life or strategies in practice. At the same time several school career counsellors voiced an opinion that the communication with pupils organised remotely allows them to have more trust in the young person's self-determination skills, the ability to evaluate alternatives and to make the decisions that have long-term effects on their future career and the life in general.

The school career counsellors, who work remotely, are convinced that the need for conversations and professionally conducted career counselling sessions for pupils will remain. Technologies will continue to play an important role in providing group and individual career advice.

\section{Discussion}

There is a significant link between the results obtained during the discussions of the focus groups and the theoretical grounds of the previously conducted studies in Latvia, Europe and throughout the world.

The psychologist R.Orska described various reasons for the conduct of teenagers that can have an effect on their willingness or unwillingness to cooperate with a school career counsellor or any other specialist during the decision making process of important matters of their life. In this sense, professional tolerance and empathy allowing to understand the reasons of cognitive, sociocultural, educational, psycho-affective and personal development of the teenager's attitude (Orska, 2006) are essential. Tolerance and confidentiality, especially in relation to any third persons - parents, teachers, school's management and support personnel (Brennan, 2013), are the personal qualities all school career counsellors must possess and they are also part of the Professional Code of Practice of Latvian school career counsellors. It has been developed on the basis of the Ethical Standards of the international career counselling organisation IAEVG. The school career counsellors, who took part in the empirical research, emphasised tolerance, confidentiality and trustworthiness, and indicated that the client's long-term trust can be achieved if the pupil has had an opportunity to observe these qualities in daily communication with a counsellor. Therefore, pupils are much more confident and take much more pro-active part in the modelling of their career development plan when the career counselling session takes place remotely. The situation gets more complicated if the first counselling session takes place remotely and there is no prior experience of communication and no information about each other for the parties involved. The IAEVG puts an emphasis on the career counsellor's respect for his profession, his own needs and the necessity of professional development; it also calls for training the ethical sensitivity and empathy through various professional support events, such as, supervisions, co-visions, other exchange of experience activities (IAEVG, 2017). The

\section{info@icfte.com www.icfte.com}




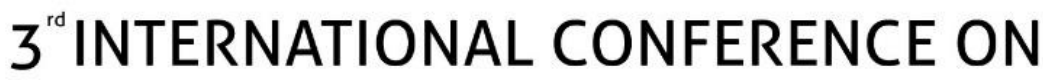 FUTURE OF TEACHING \& EDUCATION}

positive impact of supervisions in the development of career counsellors and other specialists of counselling professions has been analysed a lot in the most recent theoretical literature (McLeod \& McLeod, 2011; Burceva, 2019; Burceva, 2020).

Other researchers develop the career construction theory, also paying attention to the conditions that facilitate to the formation of career management skills, the content and quality of career counselling services, and the methodology for the development of realistic career plans, including in the multicultural environment (Savickas, 2002; 2005; 2009; Amundson, 2009; Ivey, Ivey \& Zalaquett, 2018). The participants of the focus group discussions also expressed their interest and understanding of the specific questions of counselling, linking them with the peculiarities of the remote work and proving their competence. Several scientists have turned to the theoretical research of the school career counsellor's competence (Ivey \& Bradford-Ivey, 1999; Egan, 2002; Sulcs \& Ertelts 2008), and the counselling modules developed by them are used in study programmes and in further education for teachers learning the basics of the professional activity of school career counsellors. During the course of the discussion the school career counsellors were able to conceptualise problems and they could voice their opinions on their causes, and it demonstrated their ability to reflect and to apply their theoretical knowledge in the analysis of professional practice.

In the science mainly psychologists have turned to identity research, focusing on the professional identity, its structure and levels of development as a separate sector (Day, et. al., 2007; Kasworm, 2005; Jakovleva, 2009; Kaufman, 2004; King \& Stretch, 2013). The aspects of professional identity of a school career counsellor and the conditions for their formation have not been studies yet. Considering the answers and suggestions given by the participants of the focus groups, it can be observed that the experience of school career counsellors is based on the holistic understanding of the tackled situations, including those in the circumstances of uncertainty, and they are able to generalise problems and solutions well. Given that each focus group included representatives of the management of schools with the relevant analytical and decision making skills, then the summarisation of individual activities regarding the challenges of remote counselling sessions took place quickly, putting an emphasis on the connection between causes and consequences, and choosing one rational solution among many alternatives. During the course of the analysis of challenges in counselling remotely it turned out that the school career counsellors possess the skill of projecting a pupil's conduct and other events, which is an indicator of a high degree of competence in their professional identity.

\section{Conclusions}

Several conclusions may be formulated as a result of the quality research and the analysis of theoretical literature.

Having assessed the qualitative data gathered through the empirical research, it can be concluded that not only the descriptive component refers to the personal practical experience of the participants of the focus group, but it can also be conceptualised at the theoretical level. The understanding of the philosophy of the school career counsellors' professional activity and their flexible approach under the circumstances of uncertainty show the increase in their professional competence and the highest degree of their professional identity. School career counsellors, who have been exposed to working under the state of emergency, have gained new

\section{info@icfte.com_www.icfte.com}




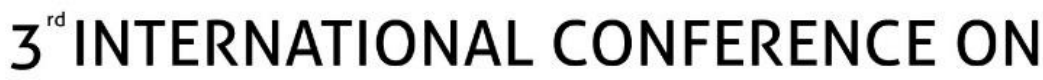 FUTURE OF TEACHING \& EDUCATION}

experience and overcome significant challenges in their profession. These challenges gave them some new, unique knowledge and tools they would be able to use under similar circumstances in the future, strengthened the professional identity as specialists, drawing them nearer to the expert level.

School career counsellors are recommended to use and improve their pupils' and their own management skills creatively, to be determined to trial new tools for remote work in groups and individualised counselling sessions, to do it not only under the conditions of crisis but also to combine these tools successfully with meeting various audiences in person (pupils, their parents colleagues, cooperation partners from outside of education institutions).

The results of the research are useful for education policy makers in order to develop new guidelines on the provision of work remotely for school career counsellors in general and vocational education institutions, and also to think through the introduction of such support measures that would potentially help to prevent job burnout.

The conclusions drawn during the course of the research on the key aspects that had an effect on the content, form and quality of the career development support in general and vocational education institutions can be used in the future in-depth studies on the formation of the professional identity of school career counsellors, strategies for the development of competences, the topicality of the prevention of job burnout in the professions of support.

\section{References}

Alves, S., \& Gazzola, N. (2011). Professional identity: A qualitative inquiry of experienced Counsellors/L'identité professionnelle de conseillers et conseillères expérimentés: Une étude qualitative. Canadian Journal of Counselling and Psychotherapy [Online], 45 (3), pp. 189-207. Available: proquestcom.db.rsu.lv/docview/894062549?accountid=32994

Amundson, N. E. (2009). Active Engagement. The being and doing of career counselling. Canada: Ergon Communications.

Bond, T. (2015). Standards \& Ethics for Counselling in Action (3 ed.). Thousand Oaks, California: SAGE Publications Ltd.

Brennan, C. (2013). Ethics in School Counseling. In C. M. Jungers, \& J. Gregoire, Counseling Ethics: Philosophical and Professional Foundation (pp. 301-320). New York: Springer Publishing Company.

Burceva, R. (2020) Supervision for School Career Counsellors: Supervisors' Opinion. Rural Environment. Education. Personality. Vol.13. Jelgava: LLU. Pp. 379-384.

Burceva, R. (2019) Supervīzija pedagogiem karjeras konsultantiem. Society. Integration. Education. Proceedings of the International Scientific Conference. Vol. V, May 24th25th, pp. 53-68. 


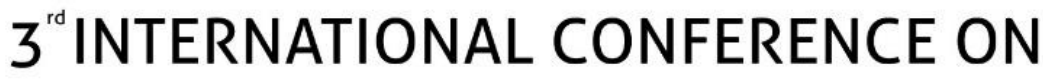 FUTURE OF TEACHING \& EDUCATION}

Stockholm, Sweden

9-11 October 2020

Day, C., Stobart, G., Sammons, P., Kington, A. \& Gu, Q. (2007). Teachers matter: Connecting work, lives and effectiveness. New York: Open University Press.

Egan, G. (2002). The Skilled Helper (7th ed.). Pacific Grove, CA: Brooks/Cole.

Ertelts, B. J. and Šulcs, V. (2008). Karjeras konsultēšanas kompetences. Rīga: VIAA.

IAEVG. (2017). IAEVG Ethical Guidelines. [Online] Available: IAEVG: https://iaevg.com/Resources\#Ethical_S

Ivey, A. E., Ivey, M. B., \& Zalaquett, C. P. (2018). Intentional Interviewing and Counseling: Facilitating Client Development in a Multicultural Society (9 ed.). Boston: Cengage Learning.

Ivey, A., Bradford-Ivey, M. (1999) Intentional Interviewing \& Counseling (4th ed.). Pacific Grove, CA.: Brooks/Cole.

Jakovḷeva, J. (2009). Profesionālā identitāte profesijas apguves sākumposmā. Promocijas darbs. Daugavpils, pp. 158.

Haase, S., Francis-Smythe, J. (2005). Career Competencies - A New Aproach to Successful Individual Career Develpoment. University of Wocester.

Kasworm, C. (2005). Adult Student Identity in an Intergenerational Community College Classroom. Adult Education Quarterly, 56, pp. 3-20.

Kaufman, P. (2004). Forming identities in college. A sociological approach. Research in Higher Education. 45 (5), pp. 463-496.

King, J.H. \& Stretch, L.S., (2013). A Critical Analysis of Counseling's Professional Identity Crisis. Ideas and Research You Can Use: VISTAS 2013. Available: https://www.counseling.org/docs/default-source/vistas/a-critical-analysis-of-counselings-professional-identity-crisis.pdf?sfvrsn $=30 \mathrm{f} 7274 \mathrm{c} \_10$

Kroger, J., \& Marcia, J. E. (2011). The Identity Statuses: Origins, Meanings, and Interpretations. In S. J. Schwartz, K. Luyckx, \& V. L. Vignoles (Eds.), Handbook of Identity Theory and Research (pp. 31-53). New York: Springer-Verlag.

Majore-Dūšele, I. (2016). Ėtiskie apsvērumi konsultēšanā un psihoterapijā. K. Mārtinsone, Konsultēšanas un psihoterapijas teorija un prakse (pp. 37-51). Rīga: Zvaigzne ABC.

McLeod, J. (2013). An Introduction to Counselling (5 ed.). New York: McGraw-Hill Education.

McLeod, J., \& McLeod, J. (2011). Counselling Skills : A Practical Guide for Counsellors and Helping Professionals (2 ed.). Maidenhead: McGraw-Hill Education.

Patton, W., McMahon, M. (2006). Career Development and Systems Theory. Connecting theory and Practice. Sense Publishers Rotterdam/Taipei.

Orska, R. (2006). Social Environment's Influence To Pupil's Behavior. Education Environment of Schools: Problems and Solutions. Scientific Articles. Rezekne, Latvia, pp. 7-17.

Savickas, M. L. (2005). The Theory and Practice of Career Construction. Career Development and Counseling. NJ: John Wiley \& Sons. 


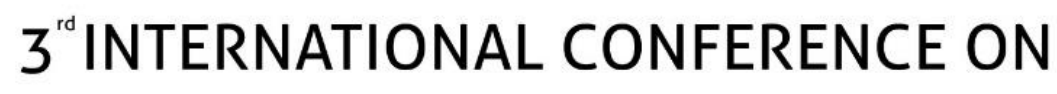 FUTURE OF TEACHING \& EDUCATION}

Stockholm, Sweden

9-11 October 2020

Savickas, M. L. (2000). Renovating the psychology of careers for the twenty-first century. The future of career. New York: Cambridge University Press.

Savickas, M. L. et al. (2009). Life designing: A paradigm for career construction in the 21st century. Journal of Vocational Behavior, 7 April 2009. 